\title{
PERANCANGAN VISUAL BRANDING HAMPER DAN GIFT WANDERLAND
}

\author{
Felisia Nova ${ }^{1}$, Bing Bedjo Tanudjaja ${ }^{2}$, Daniel Kurniawan ${ }^{3}$ \\ Desain Komunikasi Visual, Fakultas Seni dan Desain, Universitas Kristen Petra, \\ J1. Siwalankerto No. 121-131, Surabaya \\ 1e12170085@john.petra.ac.id \\ 2abimanyu@petra.ac.id \\ ${ }^{3}$ daniel.kurniawan@petra.ac.id
}

\begin{abstract}
Abstrak
Bisnis hamper ataupun gift merupakan salah satu jenis bisnis yang sedang trend dengan kebutuhan yang terus meningkat tiap harinya. Hal tersebut kemudian menjadi latar belakang dibentuknya perancangan kali ini, yaitu Wanderland. Wanderland merupakan sebuah bisnis yang bergerak dalam bidang handmade sabun yang berfokus pada pembuatan hamper atau gift box sabun. Wanderland sendiri merupakan binsnis yang masih dalam tahap perancangan sehingga sangat membutuhkan identitas visual yang jelas agar dapat diterima dan dikenali masyarakat dan membedakan diri dengan kompetitor- kompetitor lain yang bergerak pada bisnis yang sama. Tidak hanya sekedar identitas visual, namun Wanderland yang masih dalam tahap perancangan ini juga memerlukan strategi promosi media yang tepat sehingga dapat menarik target audience yang dituju. Sehingga, tujuan dari perancangan kali ini adalah untuk membentuk visual branding Wanderland yang dapat menonjolkan citra dari brand agar Wanderland dapat memiliki image yang baik di masyarakat dan dapat terus berkembang untuk kedepannya. Untuk mencapai tujuan yang diinginkan tersebut, maka diperlukan pengumpulan data dan juga metode penelitian, dimana perancangan kali ini pengumpulan data dilakukan secara kualitatif melalui wawancara, observasi, studi literatur, dan juga dengan melakukan analisis SWOT yang berorientasikan pada faktor internal dan juga eksternal dari brand.
\end{abstract}

Kata kunci: Hamper Wanderland; Wanderland; Branding; Packaging

\begin{abstract}
Hamper or gift business is one type of business that is trending which demands is continuing to increase everyday. This then became the background for the making of the design this time, namely Wanderland. Wanderland is a business that is engaged in handmade soap, which focuses on making soap hampers or gift boxes. Wanderland itself is a business that is still in the design stage, so it really needs a clear visual identity so that it can be accepted and recognized by the public and differentiates itself from other competitors engaged in the same business. Not only a visual identity, but Wanderland, who is still in the design stage, also needs the right media promotion strategy so that it can attract the intended target audience. So, the aim of the design this time is to form Wanderland's visual branding that can highlight the image of the brand in the hope that Wanderland can have a good image in the community and can continue to develop in the future. To achieve these desired objectives, data collection and research methods are needed, where the design this time the data collection is done qualitatively through interviews, observations, literature studies, and also by conducting a SWOT analysis which is oriented towards internal and also external factors of the brand.
\end{abstract}

Keywords: Wanderland Soap; Wanderland; Branding; Packaging 


\section{PENDAHULUAN}

Dalam bahasa inggris, hamper memiliki artian sebagai keranjang, terutama keranjang yang diayam. Hamper sendiri erat dengan bentukan yang relatif besar dan berisikan makanan. Namun, saat ini pengertian hamper tidak hanya sekedar sebagai keranjang besar dengan isian yang makanan saja, namun hamper sekarang memiliki bentuk yang bermacam- macam sesuai dengan keinginan konsumen dan juga menyediakan dengan acara hari-hari besar dengan isian yang beranekaragam dan bervariasi (Yurivito, 2019).

Menurut Davina (2020), kebutuhan masyarakat akan hamper ataupun gift box dalam melengkapi hari- hari spesial maupun hari- hari besar sedang meningkat. Hal tersebut juga didukung oleh data yang diberikan oleh Google Trends (2021) 5 tahun terakhir dengan data grafik pencarian untuk gift box yang terus meningkat apalagi pada saat menjelang hari raya atau hari besar. Ditambah dengan adanya pandemi virus COVID- 19 yang membuat keluarga, kerabat dan sahabat tidak bisa berkumpul, membuat hamper dan gift box menjadi salah satu cara untuk menungkapkan kasih sayang, rasa rindu, dan cinta kepada orang- orang terdekat, ataupun untuk menjaga komunikasi dan hubungan dengan orang lain (Yurivito, 2021). Kebutuhan hamper dan gift box sendiri saat ini tidak hanya sebatas isian saja, namun masyarakat zaman sekarang juga memperhitungkan keunikan dan keindahan visual dari hamper atau gift box yang diberikan, baik dari segi isi dan juga kemasan.

Dengan meningkatnya kebutuhan dan keinginan masyarakat akan hamper atau gift box, maka Wanderland hadir untuk memberikan hamper dan gift box yang unik dan menarik bagi masyarakat. Wanderland merupakan bisnis hamper dan juga gift yang berfokus pada handmade soap atau sabun buatan tangan yang alami dan natural. Keunggulan dari Wanderland sendiri adalah isian hamper yang tidak biasa, yaitu handmade sabun dan juga service yang nantinya akan disediakan oleh Wanderland berupa custom hamper dan juga custom handmade sabun sesuai dengan permintaan konsumen. Sabunsabun buatan Wanderland merupakan sabun alami dengan bahan- bahan natural yang memiliki banyak manfaat untuk kulit.

Hamper atau gift box milik Wanderland sendiri dikemas secara apik dan menarik dengan desain yang minimalis dan natural untuk lebih menekankan image dari brand dan menarik perhatian target audience. Image brand sangatlah penting untuk dibentuk dengan baik mengingat target audience Wanderland yang merupakan generasi milenial dengan karakteristik pembelian tersendiri. Dimana menurut Angela Woo (2018), genereasi milenial lebih cenderung untuk membeli berdasarkan value on experience serta ingin apa yang mereka beli dapat membuat mereka merasa baik dan lebih mengarah pada personality mereka. Maka dari itu, identias visual dari brand dan juga image yang akan menggambarkan brand nantinya akan sangat penting bagi Wanderland untuk melangkah kedepannya.

Wanderland sendiri merupakan bisnis yang masih pada tahap perancangan dan belum secara resmi diluncurkan. Wanderland berlokasi di Surabaya dan dijalankan oleh perseorangan dan berfokus pada hamper dan gift handmade sabun. Pemilik melihat adanya peluang pada bisnis hamper dan juga gift yang mengalami peningkatan di masyarakat. Oleh karena itu, kebutuhan Wanderland akan branding yang tepat nantinya akan menjadi bagian yang crucial bagi Wanderland agar dapat diterima oleh masyarakat dengan baik.

Pada perancangan visual branding kali ini, dibutuhkan beberapa landasan teori untuk mengindentifikasi permasalahan yang ada. Berikut merupakan landasan-landasan teori yang diperlukan.

Brand merupakan representasi keseluruhan sebuah bisnis ataupun perusahaan yang berhubungan dengan pengidentifikasian sebuah produk dan pembedanya dengan kompetitor melalui penggunaan logo, desain, atau visual simbol dan elemen lain (Heding, Knudtzen, Bjerre, 2009).

Branding dapat didefinisikan sebagai banyak hal, mulai dari pembuatan logo, promosi, dan lain sebagainya. Branding sendiri merupakan tulang punggung yang menyangga sebuah perusahaan dengan mendefinisikan posisi bagi bisnis atau perusahaan di pasaran, memberikan arahan arah dan visi pada perusahaan atau bisnis (Melissa, 2009). 
Consumer insight merupakan interpretasi yang digunakan untuk memahami tentang konsumen serta apa yang mereka butuhkan dan pikirkan agar dapat memprovokasi aksi dari konsumen. Consumer insight merupakan salah satu alat crucial yang memberikan transformasi pada bisnis model dari yang product- centric ke cosumer-focused (Truong, 2019).

Brand essence merupakan inti atau core dari brand yang biasanya merupakan sebuah kalimat pendek yang menyimpulkan atau melambangkan hati dan jiwa dari brand (Heding, et al., 2009).

Niche market merupakan sebuah market atau pasar kecil yang mencakup individu atau juga merupakan sebuah grup konsumen yang memiliki karakteristik atau kebutuhan yang sama (Sert, 2017).

Brand positioning dapat diartikan sebagaimana brand dapat memposisikan diri mereka di benak konsumen (Heding, et al., 2009).

Hamper merupakan hadiah atau bingkisan yang erat kaitannya dengan keranjang yang berisikan makanan. Hamper sendiri juga memiliki kesan yang intim dan personal karena dikirimkan bersama kartu ucapan pada hari raya maupun hari- hari spesial (Yurivito, 2019).

\section{METODE PENELITIAN}

Metode penelitian yang digunakan adalah metode analisis SWOT, dimana menurut Emet Gurel dan Tat Merba (2017) metode analisis SWOT merupakan sebuah alat yang digunakan untuk menentukan perencanaan strategi dan juga management strategi dalam sebuah usaha atau bisnis. Metode analisis SWOT sendiri merupakan sebuah metode strategis yang mapan yang membantu dalam menentukan faktor dalam organisasi dan juga faktor lingkungan.

Analisis SWOT menurut Alan Sersby (2017) terdiri dari 2 faktor, yaitu faktor internal dan juga faktor eksternal. Dimana, faktor internal merupakan faktor yang ada dalam persuahaan atau usaha yang dapat kita kendalikan, sedangkan faktor eksternal

merupakan faktor yang mungkin dapat kita kendalikan sedikit atau bahkan tidak dapat kita kendalikan. Faktor internal terdiri dari strength dan juga weakness, sedangkan faktor eksternal terdiri dari threats dan opportunity.

Sehingga, SWOT analisis merupakan sebuah proses yang mencakup 4 area berbeda dalam 2 dimensi, yaitu strength, weakness, threats, dan opportunities. Berikut merupakan penjelasan dari masing- masing faktor:

1. Strength

Stregth merupakan salah satu faktor internal yang mendefinisikan bahwa sesuatu lebih memiliki keuntungan daripada kompetitor atau pesaing lain. Atau juga dapat diartikan sebagai suatufaktor yang perusahaan atau usaha miliki yang lebih menguntungkan atau lebih baik kita lakukan daripada perusahaan atau usaha lain.

2. Weakness

Weakness juga merupakan salah satu faktor internal yang mendefinisikan sesuatu yang kurang dapat dilakukan atau kelemahan yang dimiliki suatu perusahaan atau usaha. Weakness merupakan faktor yang dihasilkan dari ketidakmampuan suatu perusahaan atau usaha untuk memanfaatkan sebuah peluang atau opportunity yang ada dengan baik serta lemah terhadap ancaman atau threats.

3. Threats

Threats merupakan salah satu faktor eksternal yang tidak dapat kita kendalikan dan merupakan situasi yang membahayakan dan tidak menguntungkan perusahaan atau usaha. Threats merupakan sebuah faktor negatif yang membuat suatu perusahaan atau usaha sulit dalam mencapai goals yang dimiliki.

4. Opportunities

Opportunities merupakan salah satu faktor eksternal yang membantu meski kita tidak memiliki kontrol atau kendali. Opportunities sendiri merupakan situasi yang menguntungkan bagi sebuah perusahaan atau usaha.

Ketika digunakan dengan baik, metode analisis SWOT dapat membantu dalam berpikir dan memberikan pengertian. Pada perancangan kali ini, metode analisis SWOT akan diaplikasikan baik pada Wanderland sendiri dan juga pada kompetitor- kompetitor 
lain yang memiliki usaha dengan jenis yang sama atau mirip.

\section{HASIL DAN PEMBAHASAN}

Wanderland merupakan sebuah usaha bisnis hamper dan gift yang masih dalam tahap perancangan dan belum diluncurkan ke masyarakat, hal tersebut membuat Wanderland sebagai sebuah pendatang baru dalam bisnis hamper dan gift yang telah memiliki banyak pesaing dengan keunikan yang berbeda- beda.

Sebagai pendatang baru dalam bisnis ini, Wanderland sangat memerlukan identitas visual yang dapat membedakan dan memberikan keunikan dibanding dengan kompetitor- kompetitor yang telah terlebih dahulu terjun ke dalam bisnis ini. Selain memerlukan identitas visual dan dapat menimbulkan kesan yang kuat dibenak konsumen, Wanderland sendiri juga memerlukan media promosi yang tepat agar masyarakat terutama target audience mengetahui keberadaan Wanderland dan juga kelebihan-kelebihan yang dimiliki oleh Wanderland.

Oleh sebab itu, perancangan konsep branding ditujukan untuk memperkenalkan Wanderland di masyarakat sehingga dapat membentuk brand awareness sebagai produk hamper atau gift box handmade sabun alami yang cocok untuk digunakan sebagai hadiah maupun souvenir saat hari- hari besar maupun hari spesial. Branding dirancang sedemikian rupa, agar dapat membentuk image brand yang kuat dan dapat diterima di masyarakat serta membedakan dari kompetitor- kompetitor lain dengan bisnis yang sama atau mirip. Tabel 1 berikut merupakan hasil dari analisis SWOT yang didapat berdasarkan faktor internal dan juga eksternal dari brand.

Tabel 1. Tabel SWOT Wanderland

\begin{tabular}{|l|l|}
\hline \multirow{5}{*}{ Strength } & $\begin{array}{l}\text { 1. Terbuat dari bahan- bahan } \\
\text { alami }\end{array}$ \\
\cline { 2 - 3 } & 2. Ramah lingkungan \\
\cline { 2 - 2 } & 3. Visual menarik \\
\cline { 2 - 2 } & $\begin{array}{l}\text { 4. Menyediakan service custom } \\
\text { hamper atau gift box dan juga } \\
\text { request sabun }\end{array}$ \\
\hline
\end{tabular}

\begin{tabular}{|c|c|}
\hline \multirow{5}{*}{ Weakness } & $\begin{array}{l}\text { 1. Bentukan dan warna sabun } \\
\text { basic karena menggunakan } \\
\text { pewarna alami }\end{array}$ \\
\hline & $\begin{array}{l}\text { 2. Bentukan hamper atau gift } \\
\text { box basic dan simple }\end{array}$ \\
\hline & $\begin{array}{l}\text { 3. Kurangnya awareness } \\
\text { masyarakat akan handmade } \\
\text { sabun dan juga brand karena } \\
\text { masih dalam tahap perancangan }\end{array}$ \\
\hline & $\begin{array}{l}\text { 4. Harga cukup bersaing dengan } \\
\text { kompetitor }\end{array}$ \\
\hline & $\begin{array}{l}\text { 5. Belum memiliki identitas } \\
\text { visual dan juga media promosi }\end{array}$ \\
\hline \multirow{6}{*}{ Opportunities } & $\begin{array}{l}\text { 1. Tidak banyak hamper dan } \\
\text { gift yang bergerak pada bidang } \\
\text { sabun handmade sebagai isian }\end{array}$ \\
\hline & $\begin{array}{l}\text { 2. Produk yang alami dan } \\
\text { natural sedang trend }\end{array}$ \\
\hline & $\begin{array}{l}\text { 3. Meningkatnya demand akan } \\
\text { hamper atau gift }\end{array}$ \\
\hline & $\begin{array}{l}\text { 4. Meningkatnya tingkat } \\
\text { kesadaran target audience yang } \\
\text { melihat dan mementingkan } \\
\text { visual serta juga estetika desain }\end{array}$ \\
\hline & $\begin{array}{l}\text { 5. Banyaknya jumlah } \\
\text { penduduk, } \\
\text { acara, hari besar, dan juga } \\
\text { perusahaan yang ada di }\end{array}$ \\
\hline & $\begin{array}{l}\text { 6. Produk custom hamper atau } \\
\text { gift merupakan salah satu } \\
\text { produk yang diminati karena } \\
\text { dapat memberikan kesan yang }\end{array}$ \\
\hline \multirow{3}{*}{ Threats } & $\begin{array}{l}\text { 1. Usaha dengan jenis yang } \\
\text { sama semakin bermunculan }\end{array}$ \\
\hline & $\begin{array}{l}\text { 2.Masyarakat cenderung } \\
\text { mencari brand atau merek yang } \\
\text { sudah terkenal }\end{array}$ \\
\hline & $\begin{array}{l}\text { 3. Harga dan kualitas cukup } \\
\text { bersaing dengan kompetitor }\end{array}$ \\
\hline
\end{tabular}

Hasil dari tabel SWOT diatas baik dari segi faktor internal maupen eksternal, dijadikan acuan dalam pembuatan identitas 
visual dan juga promosi yang tepat bagi Wanderland nantinya.

Selain hasil dari SWOT, wawancara yang dilakukan dengan cara focus group discussion yang merupakan pengambilan data secara kualitatif menjadi salah satu data penting dalam mencari dan menganalisis insight dan juga kemauan serta kebutuhan dari konsumen. Berikut merupakan hasil wawancara dengan target audience, dapat disimpulkan bahwa beberapa target audience yang diwawancari memiliki masalah pada kulit seperti kulit kering, kemerah- merahan, dan lain sebagainya. Target audience yang diwawancara juga menyatakan bahwa mereka cenderung untukmemberikan gift atau hamper kepada sehabat atau kerabat dekat saat harihari besar maupun hari- hari spesial. Target audience juga merupakan seorang yang peka akan visual dan juga estetika sebuah desain dan cenderung untuk melihat visual dan juga kualitas barang akan diberikan.

Maka dari itu, dapat terlihat masalah dan kebutuhan target audience sehingga perancangan kali ini dibuat agar dapat menjawab kebutuhan dan keinginan tersebut dalam bentuk gift dan hamper Wanderland yang merupakan gift dan hamper sabun handmade yang natural dan alami dengan desain visual yang menarik. Promosi akan brand nantinya juga akan dilakukan secara online dengan melihat bahwa target audience merupakan golongan muda atau golongan millenial yang sangat dekat dengan teknologi modern.

Tabel 2. Strategi Branding

\begin{tabular}{|l|l|}
\hline \multirow{5}{*}{ Brand Essence } & $\begin{array}{l}\text { Hamper atau gift box } \\
\text { handmade soap yang } \\
\text { natural dan alami yang } \\
\text { cocok digunakan sebagai } \\
\text { gift dan souvenir untuk } \\
\text { acara- acara spesial dan } \\
\text { juga hari- hari besar. }\end{array}$ \\
\hline & $\begin{array}{l}\text { konsumen ingin suatu } \\
\text { produk hamper atau gift } \\
\text { box yang berbeda, unik, } \\
\text { dan menarik untuk } \\
\text { diberikan kepada orang } \\
\text { lain. Dimana konsumen } \\
\text { akan merasa lebih bangga } \\
\text { dengan diri sendiri apabila }\end{array}$ \\
\hline
\end{tabular}

\begin{tabular}{|c|c|}
\hline & $\begin{array}{l}\text { hamper atau gift yang } \\
\text { diberikan dipuji oleh orang } \\
\text { lain. }\end{array}$ \\
\hline Niche & $\begin{array}{l}\text { Niche atau market } \\
\text { positioning untuk } \\
\text { Wanderland, nichenya } \\
\text { akan dipetakkan } \\
\text { berdasarkan variabel bahan } \\
\text { dari produk yang alami dan } \\
\text { juga service brand yang } \\
\text { dapat melayani pemesanan } \\
\text { custom atau personalized } \\
\text { hamper atau gift box }\end{array}$ \\
\hline Positioning & $\begin{array}{l}\text { Positioning yang diperoleh } \\
\text { adalah hamper atau gift } \\
\text { box handmade soap atau } \\
\text { handmade sabun yang } \\
\text { natural dan alami yang } \\
\text { menyediakan custom atau } \\
\text { personalized hamper yang } \\
\text { cocok untuk acara dan } \\
\text { hari-hari besar. }\end{array}$ \\
\hline
\end{tabular}

\section{Konsep Desain dan Perancangan}

Konsep perancangan Wanderland didasarkan pada bahan baku handmade sabun yang merupakan bahan- bahan natural dan juga fragrance-free yang aman untuk digunakan sehari-hari serta nama hamper atau gift box Wanderland. Sehingga konsep desain yang diambil adalah natural, minimalis, dan juga feminine yang menggambarkan citra dari brand dan juga target audience. Namun, segala aspek desain tetap mempertimbangkan biaya produksi dikarenakan Wanderland merupakan produk yang masih dalam tahap perancangan sehingga desain yang dibuat haruslah ekonomis dan dapat direalisasikan.

\section{Konsep Visual Media}

Pada konsep visual, salah satu hal yang penting adalah warna yang digunakan dalam desain. Warna tidak hanya akan menjadi sebuah visual saja, namun juga menjadi suatu faktor identifikasi dari brand yang juga melambangkan brand sendiri. Pada perancangan Wanderland, warna atau tone and manner yang dipilih adalah warna- warna soft, natural, dan juga feminine. Hal tersebut dikarenakan Wanderland merupakan sebuah bisnis hamper yang alami dengan target audience yang berfokuskan pada perempuan 
sebagai target utama. Berikut merupakan color palette Wanderland.

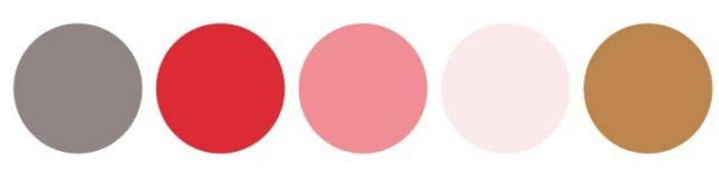

Gambar 1. Color Palette Wanderland

Wanderland sendiri menggunakan typeface serif dan juga sanserif pada logo dan juga pada aplikasi- aplikasi dsain lainnya. Kedua typeface tersebut digunakan karena memiliki kesan yang minimalis dan juga elegan serta memiliki tingkat keterbacaan yang tinggi. Wanderland menggunakan font Footlight MT Light sebagai font utama dan juga Segan Light sebagai font pendukung pada tiap aplikasi visual medianya.

abcdefghijk 1 m nopqrstuvw xyz A B C D EFGH IJKLMNOPQRSTUVWXYZ 1234567890 ?! ,.\{\};: ““

Gambar 2. Font Footlight MT Light

(Sumber: Dokumen pribadi, 2021)

abcdefghijkImnopqrstuvwxyz ABCDEFGHIJKLMNOPQRSTUVWXYZ $1234567890 ? !, .\{\} ;: " “$

Gambar 3. Font Segan Light

(Sumber: Dokumen pribadi, 2021)

Konsep logo yang disimpulkan dari hasil analisis masalah yang telah didapat adalah sebuah logo yang simple dan minimalis sehingga mudah diingat oleh konsumen. Desain konsep logo dibuat elegan sekaligus youthful yang menggambarkan kelinci dan juga busa sabun dalam bentukan sederhana agar lebih meningkatkan kesan minimalis dan juga elegan.

Logogram terinspirasi dari bentukan bintang yang melambangkan perfection dan juga gabungan antara kepala kelinci dan juga busa sabun sendiri memiliki artian kebahagiaan dan juga handmade sabun itu sendiri. Sehingga visual logo menggambarkan the perfect gift yang akan membawa kebahagiaan dan sukacita.

Nama brand Wanderland sendiri dipilih karena memiliki artian sebgai tempat pikiran yang penuh kebahagiaan atau wonder. Nama ini digunakan sebagai nama brand karena arti dari Wanderland tersebut menggambarkan brand yang bergerak pada bisnis hamper atau gift yang melambangkan kebahagiaan dan sukacita.

\section{W A N D E R L A N D HAMPER \& GIFT}

Gambar 4. Konsep Logo Wanderland

(Sumber: Dokumen pribadi, 2021)

Berikut merupakan konsep desain hamper box ukuran besar atau dapat disebut tipe The Wandrous. Konsep desain Hamper box merupakan jenis sliding box yang cara membukanya adalah dengan ditarik atau didorong. Konsep desain Hamper box besar memiliki visual serupa bentukan hati yang seberanya memvisualkan bentukan telinga kelinci yang merupakan elemen dari logo brand. Visual konsep hamper dibuat dengan desain yang minimalis dengan tone color yang natural dan feminine.

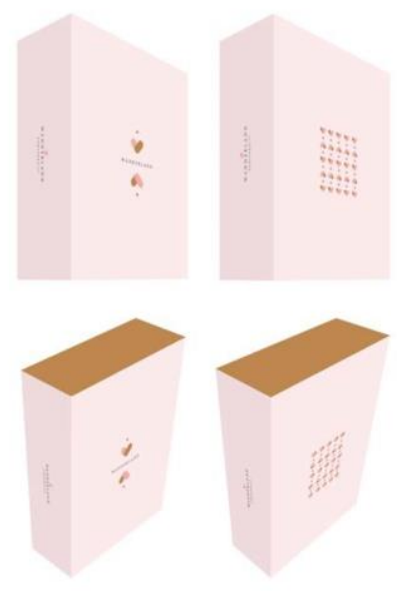

Gambar 5. Konsep Desain Hamper Box Wanderland Besar

(Sumber: Dokumen pribadi, 2021) 
Berikut merupakan hamper box ukuran kecil atau dapat disebut tipe The Petite Wander. Hamper box kecil juga merupakan jenis sliding box yang cara membukanya adalah dengan ditarik atau didorong.

Hamper box kecil memiliki visual dan makna yang sama dengan hamper box besar, namun yang berbeda hanya ukuran dan produk isian di dalamnya.

Pada hamper atau gift baik yang besar maupun kecil, akan dibuatkan sebuah alas tengah yang telah diberi pola yang menyesuaikan dengan bentuk packaging isian. Hal ini ditujukan agar produk isian dari hamper tidak akan goyah atau berubah posisi pada saat pengiriman atau transport hamper dilakukan. Sehingga pada saat konsumen membuka hamper atau gift, semua produk akan tetap tertata rapi dan berada pada posisi yang telah ditentukan.
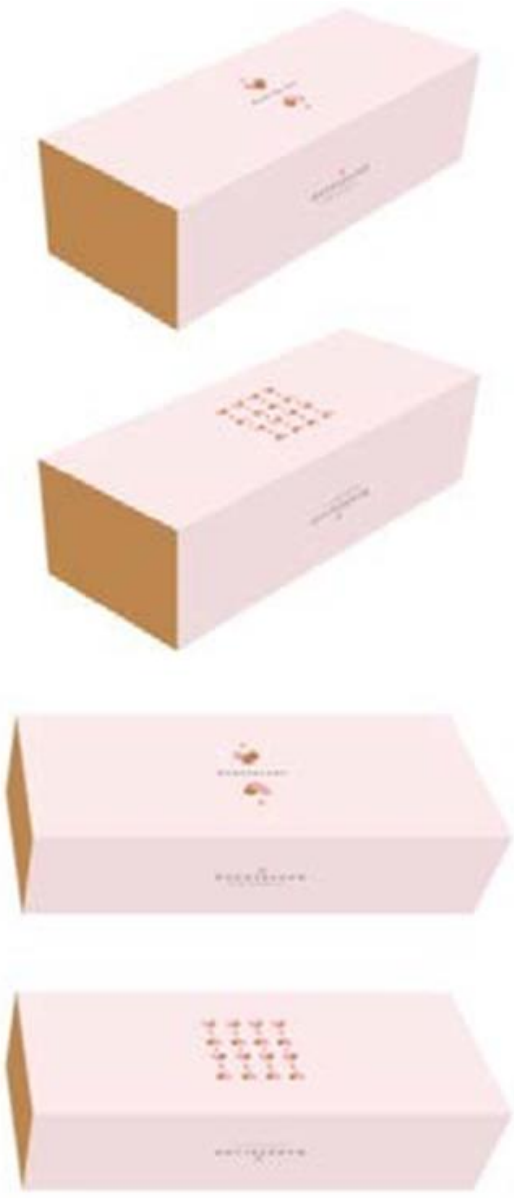

Gambar 6. Konsep Desain Hamper Box Wanderland Kecil

(Sumber: Dokumen pribadi, 2021)
Berikutnya merupakan konsep desain isian hamper. Desain kotak isian hamper berikut akan berisikan sabun batang atau sabun mandi dalam size besar. Seluruh desain isian hamper box disesuaikan dengan tone manner dan juga supergrafis.

Berikutnya merupakan konsep desain isian hamper. Desain kotak isian hamper berikut akan berisikan sabun batang atau sabun mandi dalam size besar. Seluruh desain isian hamper box disesuaikan dengan tone manner dan juga supergrafis.

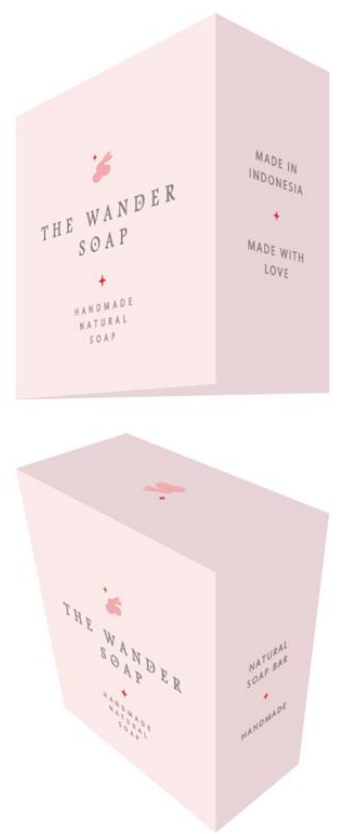

Gambar 7. Konsep Packaging Sabun Isian Hamper (Sumber: Dokumen pribadi, 2021)

Tag berguna sebagai penanda brand dan juga objek dekoratif pada hamper.

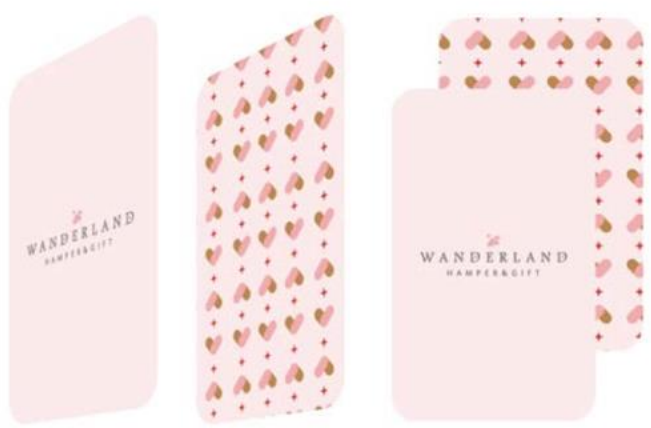

Gambar 8. Konsep Desain Tag Wanderland (Sumber: Dokumen pribadi, 2021) 


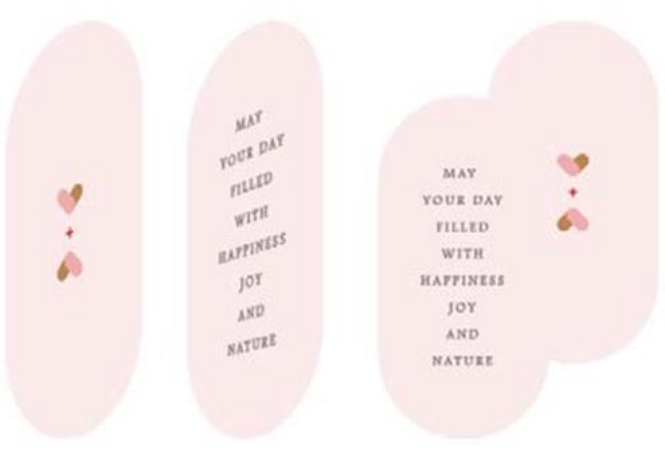

Gambar 9. Konsep Desain Tag Wanderland

(Sumber: Dokumen pribadi, 2021)

Jar pada isian hamper box ada 2 jenis dengan ukuran yang berbeda, yaitu dengan diameter $8 \mathrm{~cm}$ dan diameter $5 \mathrm{~cm}$ dengan isian sabun yang berbeda bentuk dan warna. Label dan namanya didesain dengan menyesuaikan bentukan jar dan sabun yang berbeda.
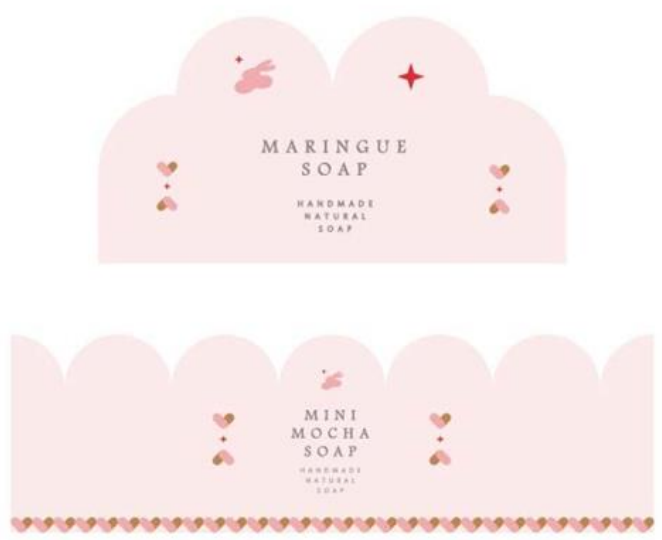

Gambar 10. Konsep Desain Label Jar (Sumber: Dokumen pribadi, 2021)

Pada hamper box besar juga akan terdapat alas sabun dari kayu yang diberi tag label Wanderland. Berikut merupakan desain visual tag label. Label alas sabun di desain sederhana dan minimalis yang kemudian akan dilingkarkan menggunakan pita pada bagian tengah dari alas sabun. Tag label alas sabun ini nantinya juga akan diikatkan pada dasar atau alas dari hamper atau gift sehingga tidak akan goyah atau berubah- ubah posisi saat hamper atau gift dikirimkan.

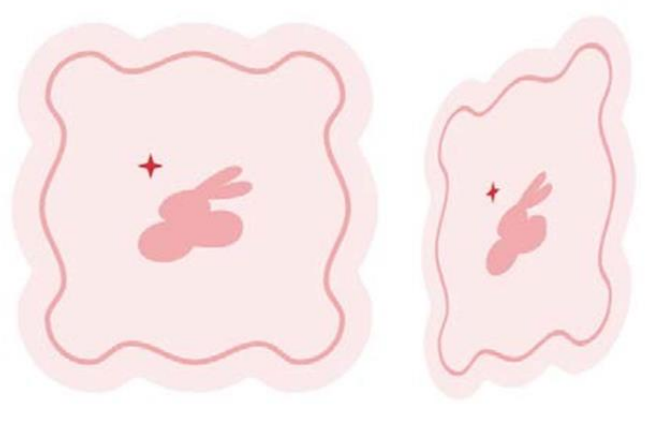

Gambar 11. Konsep Desain Tag Label Alas Sabun (Sumber: Dokumen pribadi, 2021)

Appreciation card akan diletakkan pada bagian paling atas isi hamper box, agar konsumen saat membuka hamper dapat langsung melihat appreciation card tersebut.

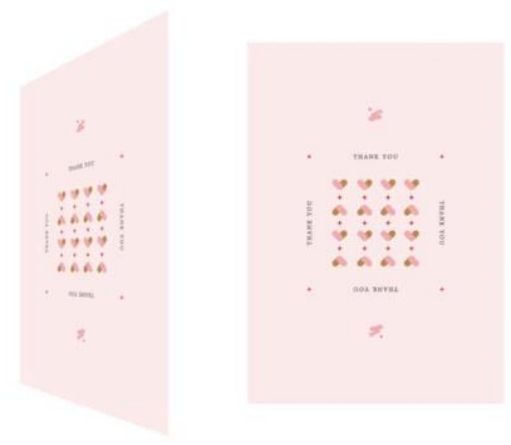

Gambar 12. Konsep Desain Appreciation Card (Sumber: Dokumen pribadi, 2021)

Berikut merupakan layout isian hamper box besar dan kecil. Layout hamper box ditata sedemikian rupa agar dapat memberikan kesan yang luwes dan juga enak untuk dilihat serta tidak terasa sesak.

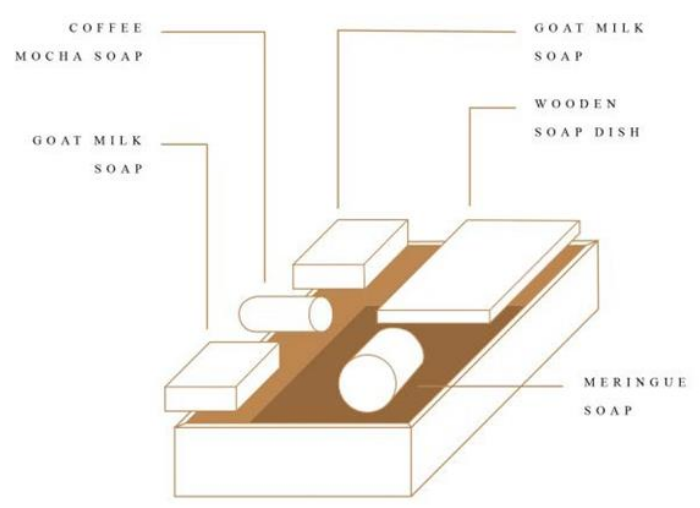

Gambar 13 Desain Layout Isian Hamper Besar (Sumber: Dokumen pribadi, 2021) 


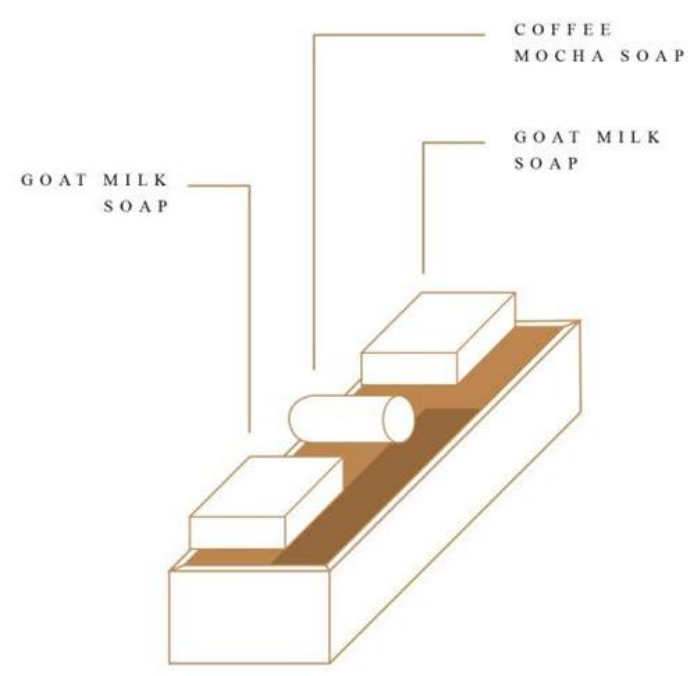

Gambar 14. Konsep Desain Layout Isian Hamper Kecil

(Sumber: Dokumen pribadi, 2021)

\section{KESIMPULAN DAN SARAN}

\section{Kesimpulan}

Wanderland merupakan brand handmade sabun alami yang bergerak pada bidang hamper atau gift box yang cocok untuk digunakan sebagai hadiah atau souvenir saat hari- hari besar atau hari spesial.

Usaha dalam bidang handmade sabun sendiri tergolong unik dan belum banyak ada di Surabaya, masyarakat juga kurang mengenal mengenai usaha handmade sabun. Hal ini membuat peluang bagi Wandererland di pasaran cukup besar. Namun, besarnya pasar juga akan memunculkan banyak kompetitor dengan jenis usaha yang sama sehingga persaingan pun akan semakin ketat. Wanderland sendiri merupakan bisnis yang masih dalam tahap perancangan, sehingga branding terhadap Wanderlan memiliki peranan yang sangat penting dan crucial agar Wanderland dapat dikenal di masyarakat dan memiliki identitas yang konsisten dan lebih mudah untuk diterima di masyarakat terutama oleh target audience. Perkenalan awal Wanderland kepada masyarakat sangatlah penting agar kedepannya Wanderland dapat terus berkembang.

Dari hasil analisis yang didapatkan, dapat dilihat bahwa Wanderland membutuhkan branding karena masih merupakan brand baru dalam tahap perancangan. Perancangan kali ini dibuat untuk menjawab masalah- masalah yang ada pada Wanderland. Perancangan merupakan pembentukan identitas visual atau branding untuk Wanderland agar Wanderland dapat memiliki identitas yang jelas dan kuat di benak masyarakat serta dapat membuat Wanderland memiliki peluang yang baik pada pemasarannya.

Keseluruhan kesimpulan dari perancangan kali ini adalah untuk memberikan identitas visual atau branding yang kuat dan jelas bagi Wanderland mulai dari pembuatan logo, pemilihan warna, hingga packaging Wanderland. Sehingga, Wanderland memiliki identitas sendiri yang unik dan dapat memiliki pembeda dari kompetitor- kompetitornya yang lain.

\section{Saran}

Berikut merupakan saran yang diberikan agar dapat memberikan manfaat baik bagi akademik, umum, maupun Wanderland sendiri adalah agar lebih memperhatikan desain secara keseluruhan karena akan memberikan dampak yang besar dari bagaimana image brand nantinya di masyarakat.

Kedepannya apabila perancangan ini dapat dikembangkan, dapat lebih berfokus pada:

1. Promosi brand dapat lebih dimaksimalkan baik secara online maupun offline (melalui bazar di mall)

2. Engagement dengan konsumen dapat lebih ditingkatkan pada social media

3. Menambah desain dan varian produk yang lebih menarik dan unik

4. Membuat website brand agar lebih dapat menjangkau konsumen secara luas

\section{DAFTAR PUSTAKA}

Davina, D., (2020, Mei 20). Hampers jadi Bisnis Silaturahmi Saat Pandemi Corona Melanda. Kompas Bisnis. Retrieved from https://www.kompas.tv/article/82116/hm pers-jadi-bisnis-silaturahmi-saat pandemi-corona- melan 
Davis, M., (2009). The Fubdamentals of Branding. Switzerland: AVA Publishing.

Gurel, E., Merba, T. (2017). SWOT Analysis:

A Theoretical Review. The Journal of International Social Research, 10(51), 113.

Google Trends. (2021, March 23). Gift Box. Retrieved from https://trends.google.co.id/trends/explore ?date $=\mathrm{t}$ oday\%205y\&geo=ID\&q=Gift $\% 20 B o x$

Heding, T., Knudtzen, C. F., Bjerre, M., (2009). Brand Management: Research, Theory and Practice. New York: Routledge.

Sarsby, A. (2016). SWOT Analysis.United Kingdom: Spectaris Ltd.

Sert, A. N., (2017). Niche Marketing And Tourism. Journal of Business Management and Economic Research., 1 (1), 14-25.

Truong, P. (2019). Insight And Its Importance In The Transactional Marketing Era [Bachelor's thesis, Centria Univesity of Applied Sciences]. Theseus Dissertations and Theses database.

Woo, A., (2018, June 4). Understanding The Reasearch On Millennial Shopping Behaviors. Forbes. Retrieved from

https://www.forbes.com/sites/forbesagencyco un cil/2018/06/04/understanding-theresearch-on- millennial-shoppingbehaviors/?sh $=413 \mathrm{bbb} 7 \mathrm{c} 5 \mathrm{f} 7 \mathrm{a}$

Yurivito, B., (2019). Jangan Sampai Salah, Ternyata Istilah Parsel dan Hamper Berbeda. Kompas Klasika. Retrieved from

https://klasika.kompas.id/baca/perbedaan -parsel-dan-hamper/

Yurivito, B., (2021). Mengenal Tradisi Mengirim Hamper Pada Hari Raya. Kompas Klasika. Retrieved from https://klasika.kompas.id/baca/tradisimengirim- hamper-pada-hari-raya/ 